\title{
Reliability Assessment of an Open Pit Slope on Bong Iron Ore Mine
}

\author{
Moses Garheyen Shannon \\ China University of Geosciences, Wuhan, China \\ Email: mo5shine@yahoo.com
}

How to cite this paper: Shannon, M. G. (2021). Reliability Assessment of an Open Pit Slope on Bong Iron Ore Mine. Journal of Geoscience and Environment Protection, 9, 31-43.

https://doi.org/10.4236/gep.2021.93003

Received: January 25, 2021

Accepted: March 14, 2021

Published: March 17, 2021

Copyright (อ 2021 by author(s) and Scientific Research Publishing Inc. This work is licensed under the Creative Commons Attribution International License (CC BY 4.0).

http://creativecommons.org/licenses/by/4.0/ (c) (i) Open Access

\begin{abstract}
Slope stability on Bong mine is crucial for securing a balance in the gross national product of Liberia. The mine is being operated using conventional open pit methods with slope angles optimally designed to maximize ore stripping quantity. However, a working slope has displayed signs of uncertainty. The overall inclination of the slope is $56^{\circ}$, and the proposed maximal excavation is $315.42 \mathrm{~m}$, but current depth in ore is approximately $50 \%$. Based on the study of slope geological characteristics, the physical and mechanical parameters of rock mass and the geometrical calculation of stoping, the study is tailored on the mechanism of inspecting stress-strain behavior in response to seasonal variation of rock moisturization as a more suitable means of stope slope stability analysis in this case. This study took full account of local rainfall and other meteorological conditions. Slope stability is investigated via stereographic projections and stability assessment using the Shear Strength Reduction (SSR) method based on FLAC (Fast Lagrangian Analysis of Continua) numerical modeling technique in three dimensions to predict the stress-strain behavior of the open-pit slope and evaluate its stability state. Global stability has been analyzed under natural and saturated conditions and it is found that the slope is critically stable and needs proper attention.
\end{abstract}

\section{Keywords}

Open-Pit Mine, Slope Stability, Factor of Safety, Strength Reduction Method

\section{Introduction}

A slope may be properly designed and implemented, yet suddenly becomes unstable and collapse at an alarming rate. Of current, slope reliability updating problem has claimed more attention (Li, Zhang, \& Jiang, 2015; Peng, Li, Li, Jiang, \& Zhang, 2014). Evaluation of slope stability in the open pit mine at dif- 
ferent stages of mining is important for the safe and economic mining operation (Sarkar \& Singh, 2007).

Bong mine, as the study area is colloquially called, is chronologically the fourth iron ore mine in Liberia. Using conventional open pit mining methods, it was initially operated by the Germans between 1965 and 1990 (Kraaij, 1983). Currently Bong Peak Mining project, owned and operated by China Union, is planned at 24 Mton (million metric tons) of ore per annum. The quality of the ore is low grade, ranging between $32 \%-35 \% \mathrm{Fe}$, and a cut-off grade of $25 \% \mathrm{Fe}$, which will all require extra beneficiation cost. Notwithstanding, owing to limited record on previous operation, a renewed rock mechanics research, which basically focused on finding a secured but economic slope angle, optimal slope angle, has been carried out ( $\mathrm{Lu}, \mathrm{Wu}$, Yuan, \& Li, 2013). In said study, the periodical rock mechanics parameters were obtained by means of Rock Quality Designation (RQD) statistics, Rock Mass Ratio (RMR) classification, Hoek-Brown analysis. Then the similar slope zoning, established by fuzzy comprehensive evaluation was divided into three main zones (A, B, C Zones), further carefully split into 12 inferior zones (A1, A2, A3, A4, A5, B1, B2, B3, B4, C1, C2, C3, Inferior Zones) (Lu et al., 2013), according to the periodical rock mechanics parameters and the bottom elevation of open pit and the geometrical shapes firstly (Laubscher, 1990). Slopes are generally cut as steep as possible to maximize the resource recovery, while geological characteristics of A2 Inferior Zone (partition characterized by the worst geological conditions at the time) were used as key determinant factors for slope and step parameters.

However, currently, a closer inspection on zoning has shown that the slope partition in B2 Zone (see Figure 2), which is the main transport line sector, is characterized by a hazardous joint set. The proposed ore recovery depth limit is estimated at $315.42 \mathrm{~m}$, but less than $50 \%$ of this target has been reached thus far. Meaning, a substantial amount of the resource and considerable depth is yet pending excavation. Considering the adverse impact discontinuities have on slope stability within rock mass (Barton \& Choubey, 1977; Hudson \& Harrison, 2000) and how their presence influences the design and maintenance of open pits (Faramarzi, Zare, Azhari, \& Tabaei, 2017), a re-estimation of slope stability that takes into account ruinous parameters became indispensible. And adopting a different, yet effective method for calculating Factor of Safety (FoS) was also an urgent appeal.

In this study, slope stability is investigated via stereographic projections and result oriented stability assessment using the SSR method based on FLAC numerical modeling technique in three-dimension to predict the stress-strain behavior of the open-pit slope and evaluate the stability state. Several researchers (Kincal, 2014; Obregon \& Mitri, 2019) have proven the usefulness of stereographic projection method for the rapid and efficient determination of the relationships between discontinuity sets in rock masses of open pits. Whereas, the efficacy of FLAC code is justified through its preferential application for estimating the FoS of rock slopes (Sjöberg, 1999; Song \& Han, 1999). 
As shown in previous study by (Lu et al., 2013), rainfall data from a southern (coastal zone) station $72 \mathrm{~km}$ away were used. But recent report by (LHS, 2021; Travel, 2021) has shown that precipitation is more abundant coastally, and decreases as one moves inland. The present study uses iso-latitudinal data of a more proximal $(46 \mathrm{~km})$ station, thus reflects the actual rainfall situation at the mine. Secondly, to better predict stress-strain behavior of the open-pit slope, SSR method was applied using seasonal variation in rock-mass moisture content. To the best of the author's knowledge, this approach is very effective, uncommon, and generates best suited results for improving mine-safety monitoring in this case.

The remainder of this study is in the following format. Section 2 gives a description of the study area. Section 3 discusses the hydrological and geologic-structural characteristics. In Section 4, the methodology employed and rock mechanics data are presented. Numerical simulation results are discussed in Section 5. Whiles Section 6 conveys the conclusion drawn from the study with the key findings.

\section{Overview}

\subsection{Study Area Location}

Bong iron ore mine is located in central Liberia (Figure 1), the southwestern part of Bong County, lying northeast of the capital Monrovia with $78 \mathrm{~km}$ away as the crow flies ( $\mathrm{Wu}, 2013)$. The straight line distance westward, between the mining district and Haindii (St. Paul River basin rainfall station) is about $46 \mathrm{~km}$. Specifically, B2 Zone (incontiguous to A2 Zone) lies along the mid-south berth of the mine as shown in (Figure 2).

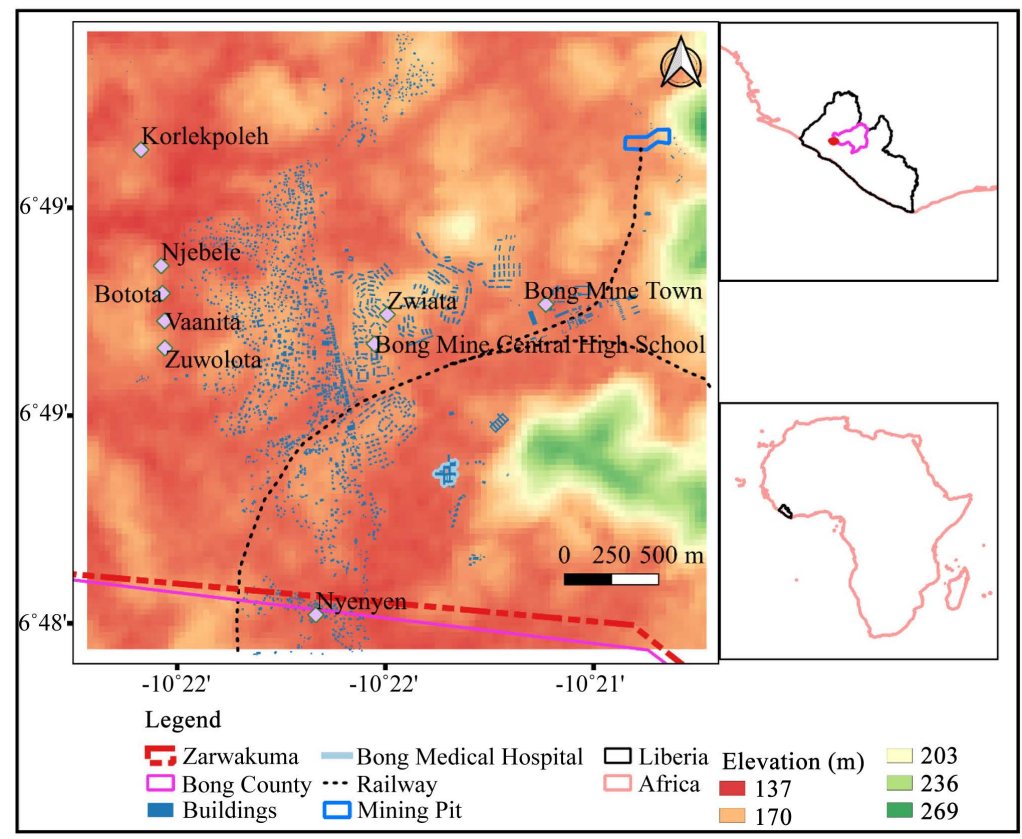

Figure 1. Location map of the study area. 


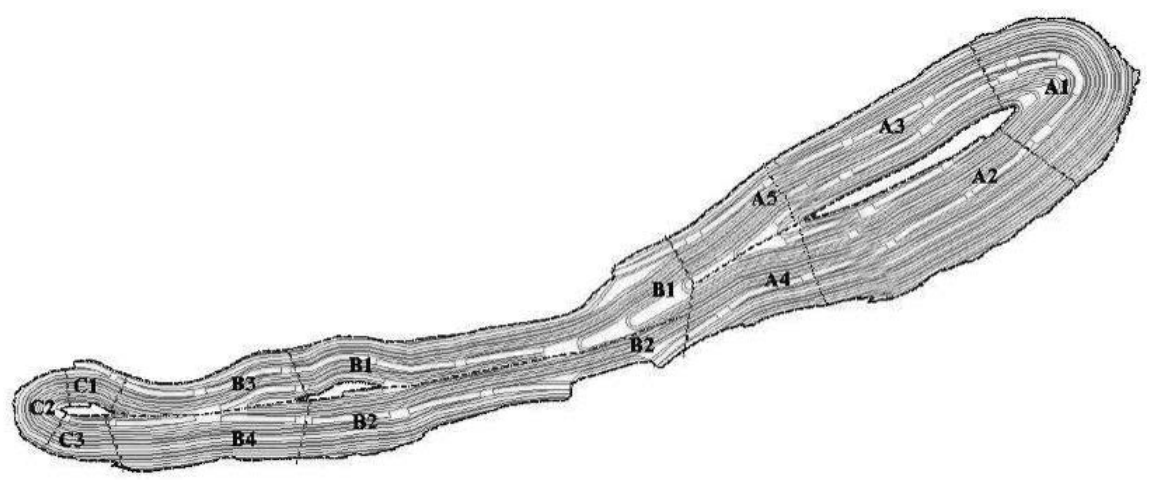

Figure 2. Schematic diagram of mine partitions.

Its striking relevance is vested in its degree of connectiveness between the east and west mine faces, linking to the railway line by which the metallic ore is transported to Monrovia port for export, thus forming an economic corridor.

\subsection{Geology}

In plate division, Liberia belongs to the African plate and is part of the West African craton man terrain. It consists of crystalline shield composed of older series of granulite mixed gneiss, hornblende and a small amount of granite. The actual crystalline shield comprises ancient intrusive bodies and metamorphic supracrustal rock series, which are both generally trending northeast. The younger strata are unconformable over the older Archean gneisses and greenstone belts, consisting mainly of quartz-rich banded iron formations, as well as amphibolite, mica schist and quartzite.

Rocks in the mining area, for the most parts are metamorphic complexes. These Archean rocks have been influenced by two orogenies, the earlier undertaken by Leonian (2.9 to 3.5 billion years), and the latter by Liberian (2.5 to 2.9 billion years). In area B2, the south-central part and main transport line sector, biotite amphibolite schist, iron quartzite, quartz muscovite schist and amphibolite quartzite are mainly distributed in the mining boundary from the pit bottom to top.

\section{Site Investigations}

\subsection{Hydrological Conditions}

Liberia has a tropical monsoon climate, divided into raining season, from May to October, and dry season, from November to April of the following year. The annual precipitation ranges from $2500 \mathrm{~mm}$ to $5000 \mathrm{~mm}$, and annual maximum rainfall exceeds $5000 \mathrm{~mm}$, making it one of the most popular areas of rainfall on the west African coast, known as the African Rainfall Capitol. The humidity is as high as $85 \%$ to $95 \%$, with highest and lowest temperatures at $34^{\circ} \mathrm{C}$ and $23^{\circ} \mathrm{C}$ respectively, and annual average temperature is $25^{\circ} \mathrm{C}$.

Specifically, in the mining area, rainfall peaks in September. The rainy season is usually characterized by long, intense, heavy or extra-heavy rain that occurs 
from time to time and forms a local rainstorm center. Groundwater effects for early stages of mining are thought to be insignificant. However, continuous rain with long and strong rain features must by no means be overlooked. Moreover, much attention should be placed on torrential downpours as external dynamic conditions that induce geologic disasters. Meteoric water, depending on joint aperture and dip direction, could pose an inflow threat. Figure 3 shows the monthly average rainfall variation meticulously collected by Liberian Hydrological Services between 2011 and 2020.

Months between November and April statistically display lower than $30 \mathrm{~mm}$ of average rainfall whereas those from May to October exhibit moderate flux density and are a source of perturbational surface runoff. The main surface water bodies in the mining area include seven pit lakes, weiting river in the north and reservoir water bodies in the south. The surface hydrological network is mostly seasonal gullies that are directly replenished by rainfall. Their discharge varies with the amount of rainfall, and has the characteristic of rapid rise and fall. During the raining season, traffic streams are often formed 2 to 4 hours after the monsoon rains, draining rapidly to the surrounding lowlands, and converging to form scattered swamps and lakes which are used by locals to enhance agricultural productivity.

\subsection{Discontinuities}

Rock slope discontinuities play a key role in the strength, permeability and stability analysis of rock masses (Barton \& Choubey, 1977; Hudson \& Harrison, 2000). Furthermore, the orientation of these discontinuities based on kinematics, highly influences rock slope stability (PRIEST, 1985, 1993). In zone B2 the dominant joint set $\left(3^{\circ} / 80^{\circ}\right)$ and slope surface $\left(343^{\circ} / 50^{\circ}\right)$, with similar inclination, intersecting at a small angle, and the inclination is greater than the slope angle, which will not endanger the stability of the slope as a whole. However, the stability of this slope is influenced by a relatively weak interlayer structural plane which exists between layered quartzite and quartz muscovite schist, and is widely developed in the surrounding rock of the ore body's direct roof. Under the

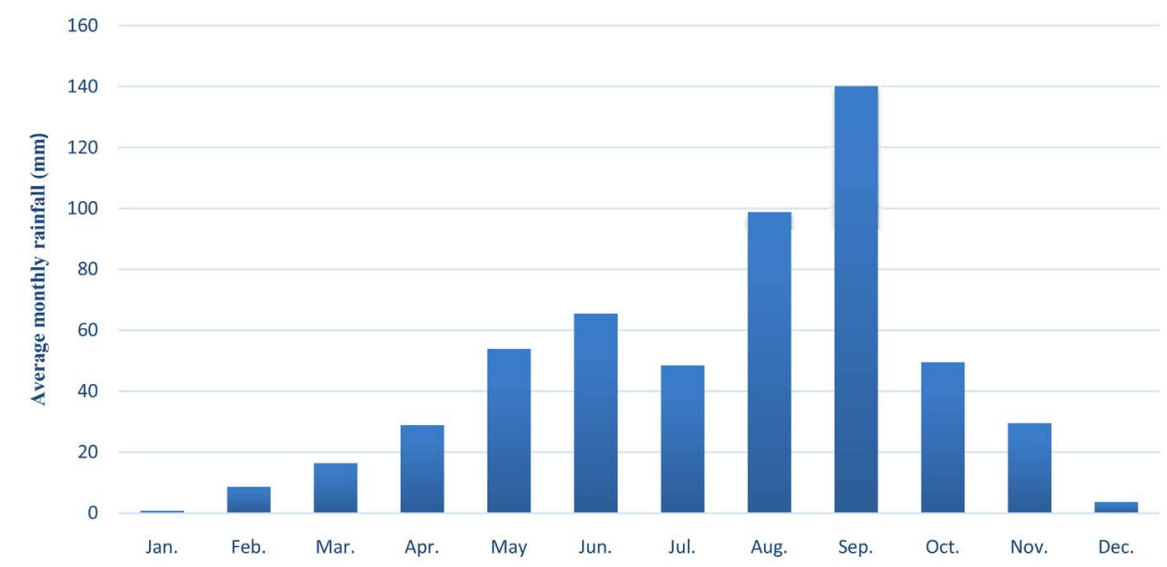

Figure 3. Average rainfall variation from 2011 to 2020. 
long term infiltration of ground water, muscovite is easily weathered, and as excavation progresses, the mine pressure is perturbed, resulting in the release of stress which may lead to a roof block collapse event. Figure 4 compares and diagnoses the relationship between joint and structural surface and slope. Figure 5(a) \& Figure 5(b) below illustrate dominant orientation of joints.

Discontinuities associated with B2 zone are inherently reversed slopes with dip angles ranging between $50^{\circ}$ and $80^{\circ}$. Reversed slopes in rock mass tend to drain ground water into the working area from the wall rock. However, considering the type and nature of filling material between the two planes of the discontinuity and the persistence thereof, an incident of groundwater inflow is improbable. Obviously, the frequency and the continuity of discontinuities are also important in this aspect.

\subsection{Pit Slope Geometry}

The mine is being operated using conventional open pit methods with slope angles optimally designed to increase ore stripping quantity. The pit slope is designed in three stages with overall inclination set at $56^{\circ}$ and a targeted depth of $315.42 \mathrm{~m}$. Figure 6 below is a diagrammatic cross section of B2 slope.

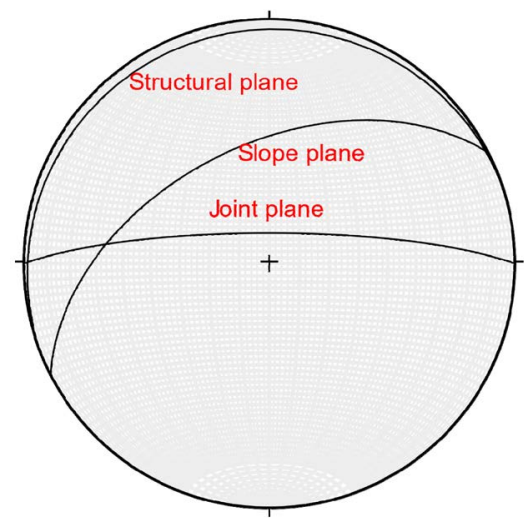

Figure 4. Stereographic plane of structural surface, joint planes.

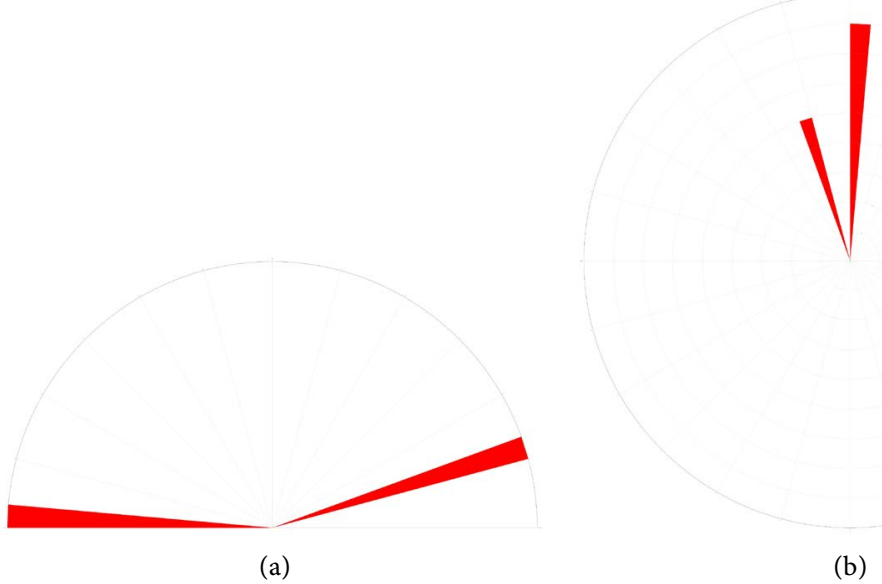

Figure 5. Rosette plots of joint set showing (a) strike; (b) plunge. 


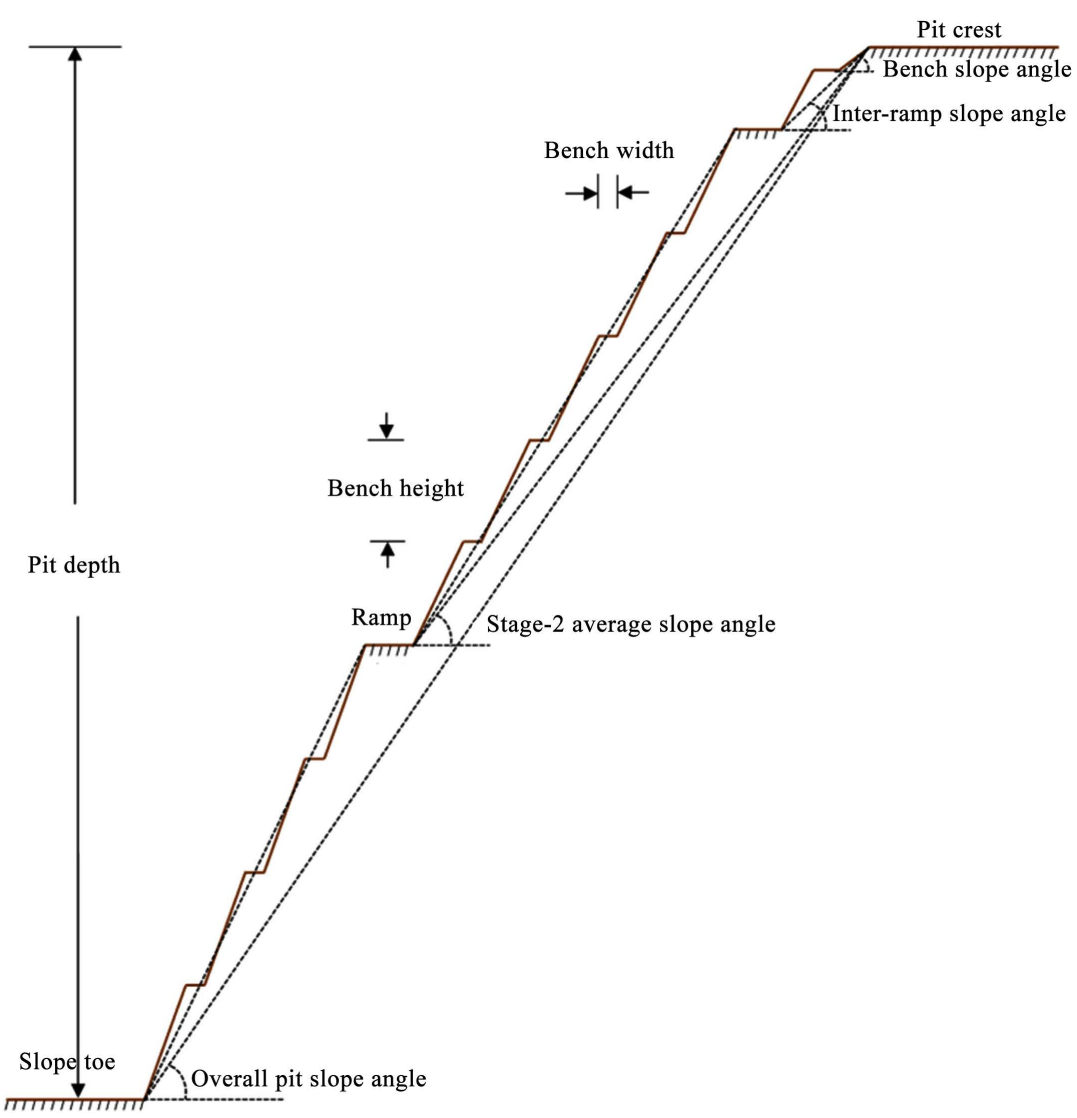

Figure 6. Slope geometry of B2 zone showing relationship between overall slope angle, inter-ramp angle and bench geometry.

Bench angles are progressively steeper to accommodate both differing geology and the layout of the ramp. The average angle at stage one is $44^{\circ}$ and stage two, $51^{\circ}$. The utmost benches are inclined at $70^{\circ}$ and the current depth in ore is approximately $50 \%$.

\section{Numerical Method}

\subsection{Sitting of Boundary Conditions}

The boundary of the domain is calculated using displacement constraints. Because the influence range of mining is limited, the displacement value of rock mass far away from the stope will be very small, and the displacement at the boundary of the calculated model can be regarded as zero. Therefore, the boundary of the computational domain adopts displacement constraint, that is, all nodes at the bottom of the model adopt $\mathrm{x}, \mathrm{y}$ and $\mathrm{z}$ direction constraints, both ends of the $\mathrm{x}$ direction of the model adopt $\mathrm{x}$ direction constraints, both ends of the $y$ direction of the model adopt $y$ direction constraints, and the top of the model is free boundary (Chang \& Zhou, 2002). Stability analysis is conducted using Mohr-Coulomb failure criterion in FLAC/Slope model. With FLAC/Slope, factor of safety is automatically calculated using the shear strength reduction method (Matsui \& San, 1992). 


\subsection{Strength Reduction Technique}

The strength reduction technique has engrafted a notable trail in rock mechanics, and is at present a significant slope stability analysis method (Dawson, Roth, \& Drescher, 1999; Hammah, Yacoub, Corkum, Wibowo, \& Curran, 2007; Yan, Su, Jiang, \& Ding, 2013; Zienkiewicz, Humpheson, \& Lewis, 1975). It is fundamentally applied in FoS calculation by reducing the rock shear strength parameters (that is cohesive force $C$ and internal friction angle $\phi$ ) to obtain a new set of values ( $c^{\text {trial }}$ and $\left.\phi^{\text {trial }}\right)$ termed trial values. A series of iterative calculations are performed using successive trial values of the factor $F^{\text {rial }}$ as new input parameters until slope failure occurs. In this case, the safety factor $F$ is defined according to the following equations.

$$
\begin{gathered}
c^{\text {trial }}=\frac{1}{F^{\text {trial }}} c \\
\phi^{\text {trial }}=\arctan \left(\frac{1}{F^{\text {trial }}} \tan \phi\right)
\end{gathered}
$$

The factor of safety ( FoS) is defined as the ratio of the total force available to resist sliding to the total force tending to induce sliding along any discontinuity surfaces (Hoek \& Bray, 1981). FoS is the most common method of slope design, and there is vast experience in its application to all types of geological conditions, for both rock and soil. Furthermore, there are formulated FoS ranges for different kinds of engineered slopes, which enhances the preparation of reasonably consistent designs. For open pit mines, FoS in the range of 1.2 to 1.4 is extensively adopted (Duncan \& Christopher, 2005).

Slope of open-pit mines fail when its material shear strength on the sliding surface is insufficient to resist the actual shear stresses (Soren, Budi, \& Sen, 2014). FoS values are by far the most understandable representation of the stability state of slopes. For FoS values greater than 1 represent stable slopes, while values less than 1 represent unstable slopes. When the ratio of material shear strength to the actual shear stress equals unity, means the slope is on the verge of failure, and such is the case as displayed in Figure 8 \& Figure 9. A slope, although stable, can be classified as critical when its FoS value falls below a specified tolerance. According to the bidding documents for the study of iron ore rock mechanics of Bong Mine Liberia, the proposed final safety factor of the slope was in the range of $1.15-1.30$.

In the process of numerical simulation, it is impossible to take into account all the factors affecting the stability of the stope slope. During the calculation, parameters most relevant to the identified problem were used in model analysis. The material parameters are listed in Table 1.

\begin{tabular}{|c|c|c|c|c|c|c|c|c|c|c|}
\hline \multirow{2}{*}{$\begin{array}{l}\text { Depth } \\
(\mathrm{m})\end{array}$} & \multicolumn{2}{|c|}{$\begin{array}{l}\text { Density } \\
\left(\mathrm{kg} / \mathrm{m}^{3}\right)\end{array}$} & \multicolumn{2}{|c|}{$\begin{array}{c}\text { Elastic Modulus } \\
(\mathrm{GPa})\end{array}$} & \multicolumn{2}{|c|}{$\begin{array}{c}\text { Cohesive force } \\
\quad(\mathrm{kPa})\end{array}$} & \multicolumn{2}{|c|}{$\begin{array}{c}\text { Internal Friction } \\
\text { Angle }\left({ }^{\circ}\right)\end{array}$} & \multicolumn{2}{|c|}{$\begin{array}{l}\text { Poisson's } \\
\text { Ratio }\end{array}$} \\
\hline & $\begin{array}{l}\text { Native } \\
\text { State }\end{array}$ & $\begin{array}{c}\text { Saturated } \\
\text { State }\end{array}$ & $\begin{array}{l}\text { Native } \\
\text { State }\end{array}$ & $\begin{array}{c}\text { Saturated } \\
\text { State }\end{array}$ & $\begin{array}{l}\text { Native } \\
\text { State }\end{array}$ & $\begin{array}{c}\text { Saturated } \\
\text { State }\end{array}$ & $\begin{array}{l}\text { Native } \\
\text { State }\end{array}$ & $\begin{array}{l}\text { Saturated } \\
\text { State }\end{array}$ & $\begin{array}{l}\text { Native } \\
\text { State }\end{array}$ & \\
\hline & 2692.5 & 2735 & 9.2 & 82 & 170 & 140 & 43.73 & 4 & 0.2 & 0.25 \\
\hline
\end{tabular}

Table 1. Input parameters for B2 slope stability analysis. 


\section{Results and Discussions}

In order to inspect stress-strain behavior in response to seasonal variation of rock moisture content, stability was analyzed as saturated and unsaturated, representing extreme conditions of raining and dry seasons. The analytical results of FLAC3D code using SSR method show slight variations in key aspects. The dry slope analysis, Figure 7 gave an FoS of 1.05, while exactly 1.0 was obtained under saturated condition as shown in Figure 8. The comparative 5\% decline in stability can directly be attributed to the influence of rainfall. Similar tendency of reduced shear strength in slope owing to rainfall effect has been reported by (He, Feng, \& Sun, 2007). The displacement contour and vector plots in Figure 9 and Figure 10 show a greater horizontal displacement value for the saturated slope, which further indicates that it is less stable. The failure surface of the slope section displayed in Figure 11 is somewise comparable to that of A2 Inferior Zone, as discussed in previous study by (Lu et al., 2013). But A2 further showed possibility of multiple planes failure. Of the two conditions analyzed,

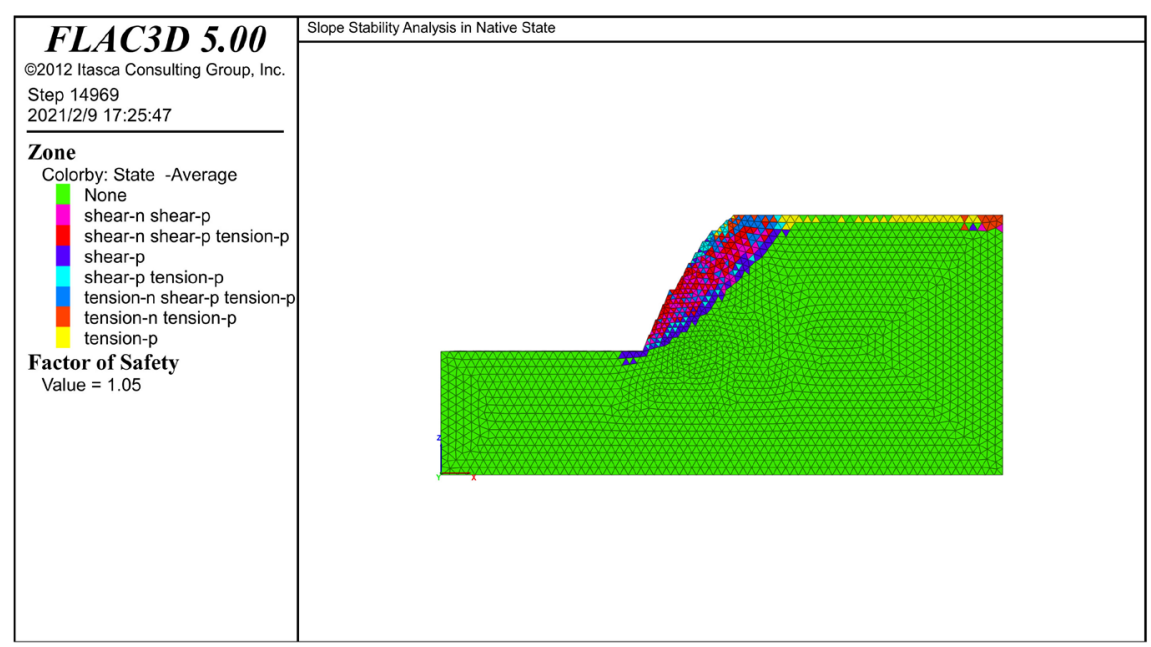

Figure 7. FLAC model showing critically stable slope in native state.

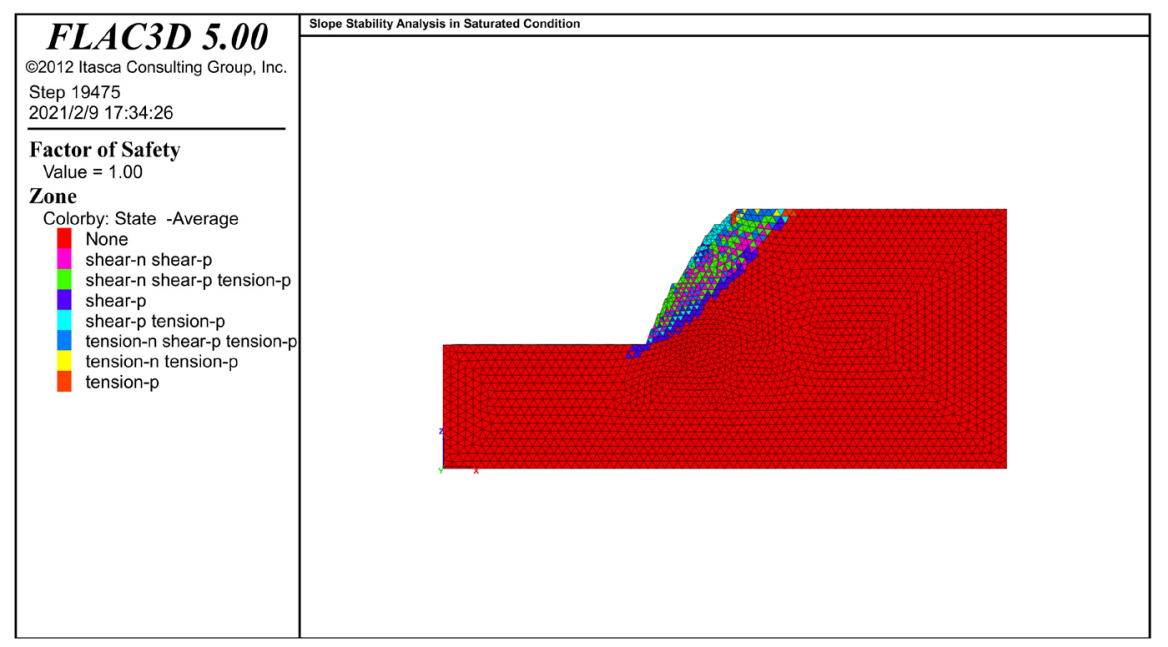

Figure 8. FLAC model showing saturated slope at incipient failure. 


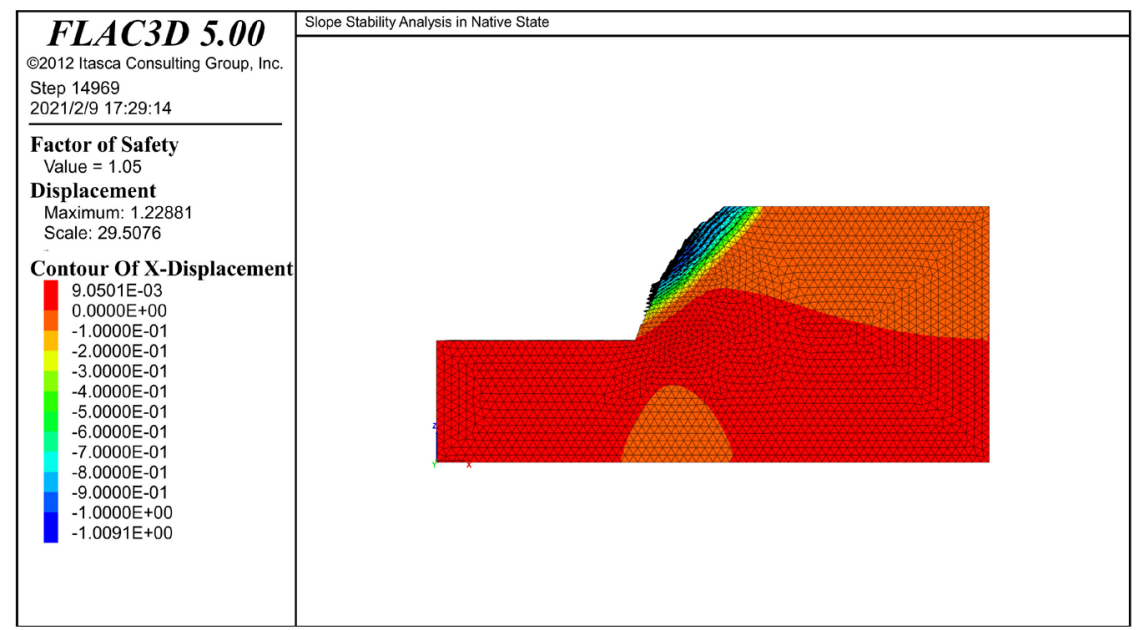

Figure 9. FLAC model showing displacement contours and vectors for plain-strain in native state.

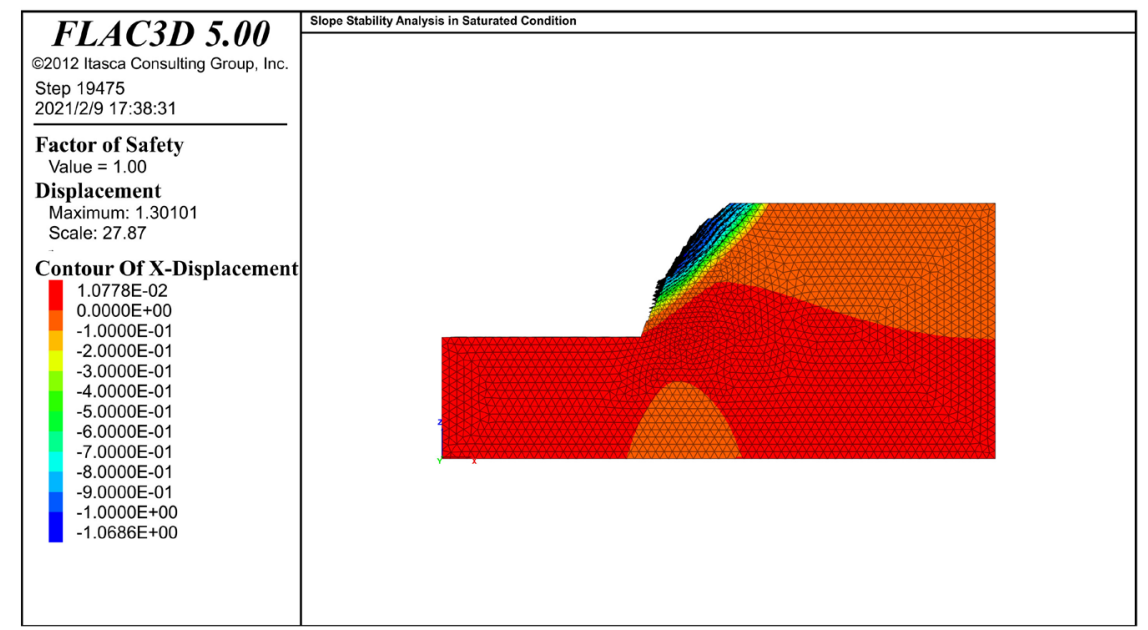

Figure 10. FLAC model showing displacement contours and vectors for plain-strain under saturated condition.

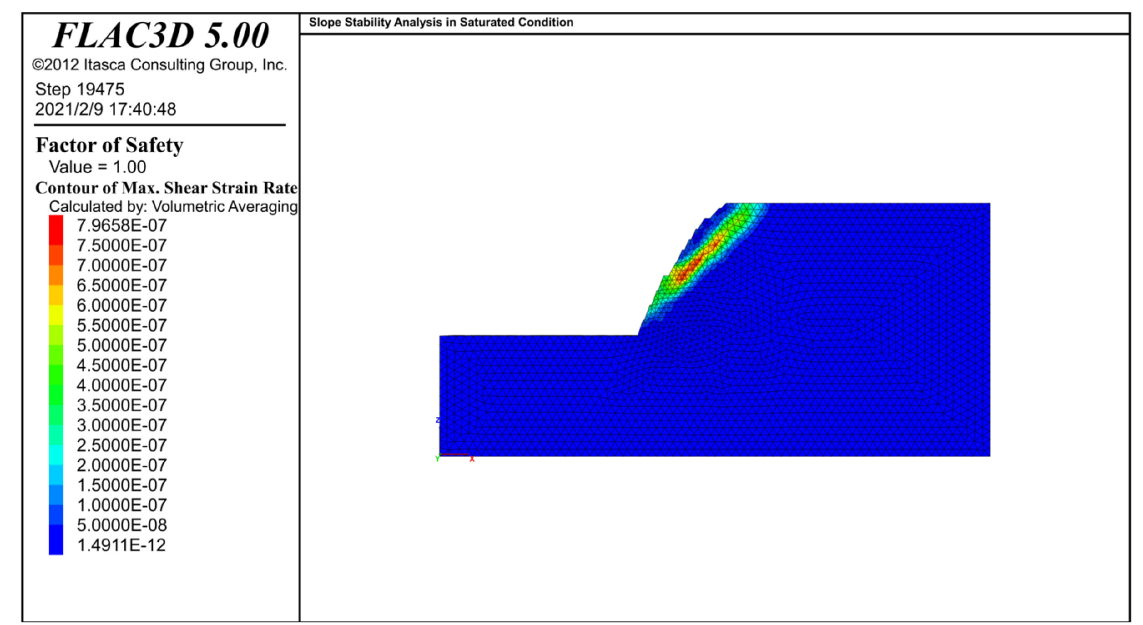

Figure 11. FLAC model display of failure surface as defined by the shear-strain contour plot. 
both states of stability are critical, yet the saturated slope indicates incipient failure, thus became the main focus. The FoS results in both cases are below the recommended acceptance criterion $(\mathrm{FoS}>1.14)$ and do not meet the stability requirement for a static condition particularly during the operation phase of deep-seated benches.

\section{Conclusion}

The present work investigated the $315.42 \mathrm{~m}$ depth slope at Bong mine for stability under saturated and unsaturated conditions and the result indicated that direct and continuous rains lead to soak of wall rocks, which lowers cohesive force and affects the overall shear strength during the raining season. The investigation took two approaches, stereographic projection and numerical simulation. The stereographic projection has shown that the joint set and slope surface intersect at a small angle with similar inclination, which generally has little impact on stability. It was further understood that discontinuities associated with B2 zone, although exhibiting an inherently dip-reversed orientation, cannot practically convey groundwater owing to their low aperture. The numerical analysis involved calculation of FoS under the two seasonal-extreme conditions using the SSR method. FoS value obtained in the native state is 1.05 , meaning the slope is critically stable. While a lesser FoS value of exactly 1.0 was obtained under saturated condition, indicating incipient failure. The present study reveals that the slope requires immediate attention to ensure long-term productivity and safety. Further investigations that encompass adjustments in stope geometrical configuration, while keeping in force the twin target of safety and profitability will need to be considered in future work.

\section{Acknowledgements}

The author expresses his sincere gratitude to Prof. Wu Li of China University of Geosciences for professional guidance, and also appreciates the technical support of engineering research teammates.

\section{Conflicts of Interest}

The author declares no conflicts of interest regarding the publication of this paper.

\section{References}

Barton, N., \& Choubey, V. (1977). The Shear Strength of Rock Joints in Theory and Practice. Rock Mechanics and Rock Engineering, 10, 1-54. https://doi.org/10.1007/BF01261801

Chang, C. C., \& Zhou, L. (2002). Neutral Network Emulation of Inverse Dynamics for a Magneto Rheological Damper. Journal of Structural Engineering ASCE, 128, 231-239. https://doi.org/10.1061/(ASCE)0733-9445(2002)128:2(231)

Dawson, E. M., Roth, W. H., \& Drescher, A. (1999). Slope Stability Analysis with Finite Element and Finite Difference Methods. Géotechnique, 49, 835-840. 
https://doi.org/10.1680/geot.1999.49.6.835

Duncan, W. C., \& Christopher, M. W. (2005). Rock Slope Engineering: Civil and Mining (4th ed., p. 10). Abingdon-on-Thames: Taylor \& Francis e-Library.

Faramarzi, L., Zare, M., Azhari, A. et al. (2017). Assessment of Rock Slope Stability at Cham-Shir Dam Power Plant Pit Using the Limit Equilibrium Method and Numerical Modeling. Bulletin of Engineering Geology and the Environment, 76, 783-794. https://doi.org/10.1007/s10064-016-0870-x

Hammah, R. E., Yacoub, T. E., Corkum, B., Wibowo, F., \& Curran, J. H. (2007). Analysis of Blocky Rock Slopes with Finite Element Shear Strength Reduction Analysis. Proceedings of the 1st Canada-U.S. Rock Mechanics Symposium, Vancouver, 27-31 May 2007, 329-334. https://doi.org/10.1201/NOE0415444019-c40

He, M. C., Feng, J. L., \& Sun, X. M. (2007). Stability Evaluation and Optimal Excavated Design of Rock Slope at Antaibao Open Pit Coal Mine, China. International Journal of Rock Mechanics \& Mining Sciences, 45, 289-302. https://doi.org/10.1016/j.ijrmms.2007.05.007

Hoek, E., \& Bray, J. (1981). Rock Slope Engineering (3rd ed., p. 27). London: The Institution of Mining and Metallurgy. https://doi.org/10.1201/9781482267099

Hudson, J., \& Harrison, J. (2000). Engineering Rock Mechanics: An Introduction to the Principles (Vol. Second Impression 2000, p. 114). London: Elsevier Science Ltd.

Kincal, C. (2014). Application of Two New Stereographic Projection Techniques to Slope Stability Problems. International Journal of Rock Mechanics and Mining Sciences, 66, 136-150. https://doi.org/10.1016/j.ijrmms.2014.01.006

Kraaij, F. P. M. V. D. (1983). The Open Door Policy of Liberia-An Economic History of Modern Liberia. Uebersee Museum. http://www.liberiapastandpresent.org

Laubscher, D. H. (1990). Mine Design: A Geomechanics Classification System for the Rating of Rock Mass in Mine Design. Journal of the South African Institute of Mining \& Metallurgy, 10, 257-272.

LHS, M. o. M. a. E. (2021). Rainfall Data. http://www.lhsliberia.com

Li, X. Y., Zhang, L. M., \& Jiang, S. H. (2015). Updating Performance of High Rock Slopes by Combining Incremental Time-Series Monitoring Data and Three-Dimensional Numerical Analysis. International Journal of Rock Mechanics and Mining Sciences, 83, 252-261.

Lu, Z., Wu, L., Yuan, Q. A., \& Li, B. (2013). Open-Pit Slope Optimal Angle of Bong Peak Mining Based on EALEE Comprehension Method. EJGE, 18, 4264-4280.

Matsui, T., \& San, K.-C. (1992). Finite Element Slope Stability Analysis by Shear Strength Reduction Technique. Soils and Foundations, 32, 59-70. https://doi.org/10.3208/sandf1972.32.59

Obregon, C., \& Mitri, H. (2019). Probabilistic Approach for Open Pit Bench Slope Stability Analysis-A Mine Case Study. International Journal of Mining Science and Technology, 29, 629-640. https://doi.org/10.1016/j.ijmst.2019.06.017

Peng, M., Li, X. Y., Li, D. Q., Jiang, S. H., \& Zhang, L. M. (2014). Slope Safety Evaluation by Integrating Multi-Source Monitoring Information. Structural Safety, 49, 65-74. https://doi.org/10.1016/j.strusafe.2013.08.007

Priest, S. D. (1985). Hemispherical Projection in Rock Mechanics (124 p.). London: George Allen \& Unwin.

Priest, S. D. (1993). Discontinuity Analysis for Rock Engineering (473 p.). London: Chapman \& Hall. https://doi.org/10.1007/978-94-011-1498-1

Sarkar, K., \& Singh, T. N. (2007). Evaluation of Instability Analysis of Slope-A Numeri- 
cal Approach. Mining Engineering Journal, 8, 11-31.

Sjöberg, J. (1999). Analysis of the Aznalcollar Pit Slope Failures-A Case Study. In Detournay, \& Hart (Eds.), FLAC and Numerical Modeling in Geomechanics (pp. 63-70). Rotterdam: Balkema. https://doi.org/10.1201/9781003078531-10

Song, W. K., \& Han, K. C. (1999). Optimal Design of Highway Slopes in a Highly Weathered Rock. ISRM International Congress, Foz do Iguassu, 13-18 September 2019, 131-133.

Soren, K., Budi, G., \& Sen, P. (2014). Stability Analysis of Open Pit Slope by Finite Difference Method. International Journal of Research in Engineering and Technology, 3, 326-334. https://doi.org/10.15623/ijret.2014.0305062

Travel, C. T. (2021). World Climate Guide. http://www.climatestotravel.com

Wu, L. (2013). Rock Mechanics Research Report to State Mine Iron Ore Project in Liberia.

Yan, L., Su, G., Jiang, J., \& Ding, L. (2013). Slope Stability Analysis under Drawdown Conditions Using Strength Reduction Technique Based on Fast Lagrangian Method. Applied Mechanics and Materials, 281, 624-629.

https://doi.org/10.4028/www.scientific.net/AMM.281.624

Zienkiewicz, O. C., Humpheson, C., \& Lewis, R. W. (1975). Associated and Non-Associated Viscoplasticity and Plasticity in Soil Mechanics. Geotechnique, 25, 671-689.

https://doi.org/10.1680/geot.1975.25.4.671 